\title{
Understanding Pakhtun Woman's Vulnerability in Negotiation with their Husbands for HIV/AIDS Screening
}

\author{
N. Khan (Nasa Khan)1', W. Khan (Waseem Khan)², A. Naz (Arab Naz)2, A. Sultana \\ (Aneela Sultana) ${ }^{3}$, A. Pasha (Asmat Pasha) ${ }^{4}$
}

${ }^{1}$ University of Chitral, Pakistan.

${ }^{2}$ University of Malakand, Pakistan.

${ }^{3}$ Qaid-i-Azam University Islamabad, Pakistan.

${ }^{4}$ M. Phil Scholar, Khyber Medical University, Pakistan.

\section{E-mail address:}

nasar_s12@yahoo.com

\section{Reprint address:}

Nasar Khan

University of Malakand

Khyber Pakhtunkhwa

Pakistan

Source: Clinical Social Work and Health Intervention

Volume: 12

Pages: $32-39$

Cited references: 27

Issue: 1

\section{Reviewers:}

Vitalis Okoth

Hargeisa, Somalia

Johnson Mawole

Nyanza, Tanzani

\section{Keywords:}

Gender. Private Relationships. HIV/AIDS. Negotiation. Inequality. Migration.

\section{Publisher:}

International Society of Applied Preventive Medicine i-gap

CSWHI 2021; 12(1): 32 - 39; DOI: 10.22359/cswhi_12_1_08 CC Clinical Social Work and Health Intervention

\section{Abstract:}

Unequal treatment of females within families is a common phenomenon and is a core concern of feminist perspectives (Macionis, 2012; Haralambos \& Holborn, 2013). In patriarchal societies women are not welcome to discuss and negotiate with men (Thompson, 1998), and this pattern prevails in private relationships as well (Saunders et al. 2017). Framed under qualitative research design, this study aims to understand Pakhtun women's vulnerability in negotiation with their husbands for HIV/AIDS screening in Dir Lower, Khyber Pakhtunkhwa, Pakistan. Purposive sampling technique has been utilized to select samples from the population of interest whereby a total of 8 samples were se- 
lected in reaching the saturation point. For collection of the information, an interview guide was designed with relevance to the research questions of the current study. The collected information has been analyzed thematically. Findings show that women exercise limited sexual authority and men are in control when it comes to personal relationships. There is very much less space for women to discuss and negotiate with men regarding use of precautionary measures. Men consider discussion and negotiation as a competing behavior from women. Thereby women are apprehended of problems in marital relationships and angry reply from husbands in discussing and negotiating with men regarding private family relationships and use of precautionary measures. Men being vulnerable to HIV/AIDS in the study area due to high rate of emigration and inability of women to discuss and negotiate regarding screening tests and use of precautionary measures are increasing the spread of HIV/AIDS among families.

\section{Background of the Study}

The gender organization of the home is an eminent factor in constructing inequalities between men and women at familial level. It is embedded in access to material resources, power, and roles within the home (Ridgeway, 2011). Men and women confront each other on the basis of material resources, power, and roles within the home. It is evident from hundreds of studies that relatively men have more access to material resources, power, and play dominant and authoritative roles within the home (e.g. in patriarchal societies). As a result, men are the decision makers within the home, and there is very much less space for women to discuss and negotiate with men, and to make decisions (Thompson, 1998; Connell, 2009; Bowles, 2012).

\section{Women and Negotiation and Persuasion in private life}

There is a plenty of evidence the in a majority of societies that women are not allowed to negotiate with men i.e. negotiation about familial matters, health, having children, to go for work etc. This trend is very common in private life as well, for instance, a wife don't ask anything from her husband. It is evident that men do not like when women ask. A man considers it as a competing behavior, and perceives it in a negative way. This pattern of relationship does not allow women to discuss and negotiate with men (Thompson, 1998).

Gender roles play a key part here, for example, men's behavior and women's behavior is sig- nificantly influenced by the roles they play in their spective situation, culture or society. Men behave in an authoritative way because of their breadwinner role for the family (Lewis, 2009) while women take care of household responsibilities. In the majority of societies the status of male in family is authoritative because of their valued role as breadwinner whereas the female being a care taker of the household is not so valued. Concomitantly, women are not welcome to negotiate or discuss with men with regard to familial matters, health, having children, to go for work etc. Thereby, women often feel anxious which prevents them from negotiation. In this regard, for instance, a survey conducted revealed that women feel anxiety and discomfort while negotiating and persuading men. The key issue whereby women felt anxiety and discomfort included asking about things women want; changing residence; asking for starting a job or work; etc. Another imperative aspect in this context is negotiation apprehension. In explanation, women fear an inappropriate answer, ignoring behavior, and problems in relationships particularly when such negotiation is with husband (Allred, 1999; Babcock \& Laschever, 2003).

As mentioned in the previous paragraph a similar situation exists in Pakhtun culture and society. Pakhtun culture and society are predominantly patriarchal where men are in control e.g. at home and at the work place. Women are not given space to discuss their desires, decisions and opinions. Such desires, decisions and opinions 
are about deciding their mate selection or marriage, education, employment, family and children.

\section{Statement of the Problem}

A private relationship (e.g. marital) is an important aspect of an individual's family life. Unfortunately there is a bulk of evidence that women in private relationships are confronted with unequal treatment; subordinate position; imbalanced power sharing. As a consequence, there is a lack of space for women to discuss and negotiate with their husbands (Babcock \& Laschever, 2003). A similar situation has been found with regard to sexual relationships. For example, a study shows that women often don't ask their partners to use condoms. There are reasons for it, for instance, women are concerned that it may lead to marital problems such as it will damage their relationships with husband. Another reason is the role playing whereby men play the role of breadwinner for family which is more valued in society than that of women's role of taking care of household responsibilities. Consequently, women are anxious and apprehensive while discussing and negotiating with men regarding private life and sexual matters (Macionis, 2012; International Organization for Migration, 2006).

Literature indicates that differential power sharing, lack of discussion and negotiation in private and marital life has negative consequences. For example, study shows that lack of space for women to discus and negotiate with their husbands about the use of condoms during sex make women vulnerable to unwanted pregnancies, venereal diseases as well as viral and bacterial infections such as HIV, Gonorrhea, etc. (Lewicki, Saunders \& Minton, 1997: Babcock \& Laschever, 2003).

Emigration to Middle East and Gulf countries for the purpose of employment is a common phenomena in the Pakhtun belt of Pakistan (Zohry, 2007). Emigrants work in Middle East and Gulf countries for years and even a decade without their families and wives. Stress and sexual frustration commonly prevails among working emigrants which increases their vulnerability to have sexual affairs (e.g. paid sex) within countries of destination. 94\% of labor migrants are away from their spouses for a year or more than a year. Labor migrants are also not bound by the socio- cultural and religious norms which governs sexuality at the country of origin. Labor migrants are exposed to extreme working conditions and even sexual exploitation. The resulting isolation and stress may lead migrant workers to engage in behaviors, e.g. unsafe casual or commercial sex, which increase HIV risk. This risk is further worsening due to the inadequate access to HIV services and fright of being stigmatized for seeking HIV-related information and support (UNDP, 2004). As a consequences, migrants are at increased risk of being infected by sexually transmitted bacteria and viruses, for example, HCV, HIV, syphilis etc. (International Organization for Migration, 2006; National AIDS Control Program, 2017). Due to higher rates of migration to Middle East, United Kingdom and Malaysia, Pakistan are included in lists of countries whereby HIV/AIDS is spreading significantly. National AIDS Control Program (NACP) in its recent report of 2016-17 there are 22,333 registered cases of HIV/AIDS in Pakistan and an estimated 0.133 million individuals are infected by HIV virus in Pakistan. Therefore, it is important on return to have a screening test and use precautionary measures to prevent the further spread of HIV/AIDS. In this regard, wives could play an eminent role to persuade their husband to have screening in order to stop further spread of HIV/AIDS. However, in light of the mentioned literature on gender related sub-ordination women often are unable to discuss and negotiate sexual matters with husbands. In this connection, this study is an effort to understand Pakhtun women's vulnerability in negotiation with their husbands for HIV/AIDS screening

\section{Theoretical Framework}

Negotiation is an essential component of human interaction. Negotiation during interaction is a part of micro level phenomenon (e.g. concerning everyday life) such as household interaction; work place interaction; interaction in Church or Mosque; etc. Similarly, in terms of relationships across sex and gender negotiation is an integral component (Weini \& Kashuba, 2012). However, studies show that there is deference in negotiation patterns across gender, for instance, women are constrained to negotiate with men. There are reasons for it which includes lack of access to resources, gender stereotypes and social 
roles. Each of the mentioned factors affects negotiation across gender in its own manner. Firstly, in patriarchal society men dominates the economic sphere of life and have access to material resources while on the other hand women are oppressed. Second, gender stereotypes, for example, considering women as less competent and unable to think rationally and logically makes women incapable to negotiate with men. Third, social role such as men being the breadwinners for family contributes significantly constrain women to discuss and negotiate with men (Macionis, 2012).

Feminist perspective emerged during 1950s, and successfully explains inequalities on familial basis across gender. Feminist perspective explains two prominent reasons of women's oppression in family; first, female are socialized in a way that they must adopt subservient roles within the family while on the contrary male are socialized to act and behave in superior way. Second, females are socialized in way to develop into a housewife, for example, taking care of children, cooking, providing emotional support, and indeed, these are defined as the only way to be feminine or woman. Thereby, feminist perspective considers family as the root cause of gender inequalities existing in society i.e. inequalities in family, education, workplace, Church or Mosque etc. For further details in this regard see Haralambos \& Holborn (2013, Chapman et al (2015).

\section{Objective of the Study}

The prominent objective of the current study is to recognize the inability of Pakhtun Women to negotiate and discuss with their husbands about HIV screening test and using precautionary measure upon return from the country of destination.

- This study is based on following research questions:

- What is the status of women with regard to sexual power in home?

- How much space and opportunity is given to women to discuss and negotiate with their husbands regarding sex and use of precautionary measures?

- What anxieties prevail among women while having discussion and negotiation with husbands about HIV screening?

- How and why women are apprehensive to dis- cuss and negotiate with husbands about HIV screening and use of precautionary measures?

\section{Material and Methods}

Study Area: This study has been carried out in Chakdara, District Dir Lower, Khyber Pakhtunkhwa, Pakistan. Dir Lower is one the areas where HIV/AIDS is spreading, and most importantly it is spreading hidden. Currently a project is working on the issue which reported there are 5,999 registered cases of HIV/AIDS in Dir Lower.

Nature of the Study: The study is framed under qualitative research design a textual representation of the information e.g. in words, and focuses on indepth understanding of an issue. For further details on qualitative research design see Nueman (2006).

Sampling: Purposive sampling technique has been utilized for the current study whereby a total of 9 women were sampled. The determination of sample size was based on the saturation point. For further details on saturation point see Saunders, Sim, Kingstone, Baker \& Waterfield et al (2017). Besides, the purposeful sampling criteria was:

- Selection of women whose husbands are/were working in Middle East

and Gulf countries for one year at least.

- The selected women should be aware of HIV/AIDS and its mode of transmission.

Data Collection: An interview guide was designed with relevance to the research questions of the current study to collect information from the sampled women. For, detailed descriptions on an interview guide as a tool for data collection see Boyce \& Neale (2006).

Data Analysis: The collected information has been transcribed and discussed thematically. For thematic method of data analysis see The University of Auckland Guide on thematic analysis.

Ethical Considerations: The issue discussed in the current study is a sensitive one. Therefore, a coding mechanism has been devised in order to keep the respondents anonymous. Respondents are presented by $\mathrm{R}$ for denoting respondents, the first alphabet of their name and then interview number. For example, John Mathew whose interview is on first number will be denoted as R-J-1. The complete list of respondents is given in the following table: 


\begin{tabular}{|c|l|c|}
\hline S. No & $\begin{array}{l}\text { First alphabet of } \\
\text { respondents name }\end{array}$ & Code \\
\hline 1 & Z & R-Z-1 \\
\hline 2 & N & R-N-2 \\
\hline 3 & N & R-N-3 \\
\hline 4 & K & R-K-4 \\
\hline 5 & A & R-A-5 \\
\hline 6 & H & R-H-6 \\
\hline 7 & M & R-M-7 \\
\hline 8 & R & R-R-8 \\
\hline 9 & S & R-S-9 \\
\hline
\end{tabular}

\section{Data Analysis: 1.6.1 Transcription}

Field information shows that women's status is very low with regard to exercise of sexual matters and private life. Men exercise sexual powers with regard to private life, and women have very limited powers. Respondents stated that men are in control when it comes to decisions regarding private life similar to other household matters whereby men are in control. A respondent illustrated that:

„....the status of man is similar in private life as to that of other household matters ...." (R-N-2)

Another respondent argued that:

„,....my husband make decision where it is about household matters or whether it is private life such as having children...." (R-R-8)

Findings indicate that there is very much less space for women to discuss and negotiate with husbands regarding sex and use of precautionary measures. The majority of the respondents (e.g.R-N-2, R-K-4, R-M-7, R-A-5, R-H-6 and R$\mathrm{R}-8$ ) opined that it is considered as a stigma if they discuss such things with their husbands. Husbands are in control about having sex and use of condom. For instance, a respondent said that:

„....husband does not appreciate such discussion. They want to be authorities in this regard (sexual discussion and negotiation) as well..." (R-H-6)

With regard to discussion and negotiation of precautionary measures a respondent stated that:

„....my husband and all of the men in this area do not like use of precautionary measures while having sex. They are ignorant and also do not like any discussion in this regard because they consider it as a competing behavior ...." (R-K-4).
Findings enumerates that women cannot ask there husband about having HIV/AIDS test on return to home. A respondent stated that:

„I cannot imagine having a discussion with my husband about screening test for HIVIAIDS “ (R-M-7).

Another woman replied that:

„... it is too difficult for me to ask my husband to have screening test for the disease...." (R-S-9).

Woman are apprehensive while discussing sex related issues with their husbands including precautionary measures such as use of condoms and screening tests for sexually transmitted diseases. Such apprehension is because of patriarchal social structure and prevailing anxieties among women in the study area.

Pakhtun society is predominantly patriarchal in nature where women are not used to ask or discuss issues, decision and opinion with their husbands. A respondent stated that:

„....husbands and male members of the family are respected and not asking them is considered as respect there. We respect their dominancy as well, and therefore we do not ask them in sexual matters as well...." (R-Z-1).

„....How can I ask my husband to have HIV/AIDS screening test. I had no such discussion with him previously, and he will not respond to it even if I had...." (R-K-4).

Another woman argued that:

„....In our family there are many emigrants to Saudi Arabia, and I am sure that no women can tell her husband for HIVIAIDS test. We (women) are not allowed to discuss our opinions with men in our family...." (R-N-2).

Women fear of Husband's reply (apprehension), for example, replies include doubt on the character of the husband reply that he is there for labor not for sex. And most important is the husband's reply that I am staying and working there to earn for family and you are persuading me to have HIV/AIDS test.

In this regard, a woman replied that:

„....my husband will be very angry if ask for HIVIAIDS test. He is there to earn for the family, and persuading him for a test will make him angry...." (R-Z-1).

A woman stated that:

„....my husband response will be very aggressive, and he will be straight forward that I doubt his character...." (R-R-8). 
A woman answered that:

„....once I had a disagreement with my husband regarding our children's education. He replied that I am here (mentioning country of destination) and facing hardships to earn money for you. Keeping his reply in this context, if I ask him to have HIVIAIDS test, his reply will be the same and even harsher...." (R-R-8).

Most importantly women fear of marital problems resulting from such negotiation and discussion. In this regard, an extract from an interview is:

„,...I want to have a discussion with my husband about certain issues but I cannot because for sure it will lead to disagreements and problems among us. And I cannot afford it because in this culture husbands are the source of social support and prestige for women...." (R-S-9).

\subsubsection{Discussion}

In patriarchal societies similar to other aspects men are in control of sexuality as supported by Babcock \& Laschever (2003). Women are provided with minimal space for discussion and negotiation with men regarding sexual matters. Therefore, woman exercise very limited sexual authority, and men control their sexual behaviors and decisions. The prominent aspects of sexual authority includes having children; deciding the number of children; use of condoms; other precautionary measures such as screening tests for sexually transmitted diseases (STD's). In this connection the studies of Thompson (1998), Ridgeway (2011), Babcock \& Laschever (2003) also state that men are in control in private relationships (e.g. marital relations) and there is minimal space for women to discuss and negotiate with husbands.

With regard to the current study, it is important to mention that emigration from Pakistan to the Gulf, Middle East and Malaysia is very common for the purpose of employment as supported by Zohry (2007). Men stay in the mentioned countries for months and years with families. As a result, work stress and sexual frustration prevails among such men, and they are vulnerable to sexual affairs (e.g. paid sex) which increase their vulnerability to sexually transmitted diseases (STD's) as well. In this context, International Organization for Migration (2006) enumerates that stress and sexual frustration prevail significantly among labor migrants, and therefore have a tendency to get involved in risky sexual behaviors which make them vulnerable to sexually transmitted diseases (STD's). In addition to it, Weini \& Kashuba(2012) assert that people remaining absent from home for long times including labor migrants are at risk of HIV infection. Keeping this in view, statistics from a local organization working on HIV/AIDS in Malakand division shows that there are 5,999 registered cases in Dir Lower, Khyber Pakhtunkhwa, Pakistan, and a major portion of which is emigrants. Therefore, screening tests upon return can prevent the spread of the disease up to some extent.

However, the study area is pre-dominantly patriarchal supported by Nazet al (2012) and men are in control of every aspect of life including private and sexual life. As a result, numerous anxieties prevail among women apprehending them to discuss and negotiate about sexual matters with husbands. These anxieties in particular include expecting negative replies from husbands. For instance, a husband can reply about doubt of his character, and emotional replies as well can lead to marital problems. In this regard, the study of UNAIDS (2012) indicates that unequal cultural, social and economic status and unaccommodating attitudes towards sex among men is a significant contributing factor in HIV spread among women in African countries.

\subsection{Conclusion}

Pakhtun society is patriarchal where women are not allowed to discuss their opinions and desires. Emigration to Middle East and Gulf countries is common among the Pakhtun belt, and due to spending many years in destination countries, emigrants are vulnerable to have sexual affairs which increases their vulnerability to STD's including HIV/AIDS. Therefore, it is important to have HIV/AIDS screening test on return. However, women are unable to discuss it with husbands due their subordinate position in society, husband aggressive response, and marital problems.

\section{References}

1. ALLRED K (1999) Anger and retaliation: Toward an understanding of impassioned conflict in organizations. Research on Negotiation in Organizations: 7 (27). 
2. BABCOCK L, LASCHEVER S (2003) Women don't Ask: Negotiation and Gender Divide. Princeton University Press, 41 William Street, Princeton, New Jersey 08540.

3. BABCOCK L, GELFAND D S, STAYN H (2002) Propensity to initiate negotiations: A new look at gender variation in negotiation behavior. Carnegie Mellon Univ.

4. BOWLES R H (2012) Psychological Perspectives on Gender in Negotiation. Harvard Kennedy School (HKS) Faculty Research Working Paperseries at: http://web.hks.harvard.edu/publications.

5. BOYCE B, NEALE P (2006) Conducting InDepth Interviews: A Guide for Designing and Conducting In-Depth Interviews for Evaluation Input. Pathfinder International. Online Available at: http://www2.pathfinder.org/site/ DocServer/m_e_tool_series_indepth_interviews.pdf.

6. CHAPMAN et al. (2015) A Level Sociology Student Book One. Collins. ISBN-10: 0007597479.

7. CONNELL R (2009) Gender Polity Publications.

8. GUEST G, MACQUEEN N (2012) Applied Thematic Analysis. Sage Publications.

9. HARALAMBOS M, HOLBORN J (2013) Sociology Themes and Perspectives. Collins. ISBN-10: 0007597479.

10. INTERNATIONAL ORGANIZATION FOR MIGRATION (2006) Briefing note on HIV and Labor Migration in MOZAMBIQUE www.iom.org.za.

11. PERI H A, SUBRAMANIAN S, SLADECKOVA V, BYDZOVSKY J, DURCOVA B, KUBALIKOVA Z, OLAH M, MATULNIKOVA L, DOKTOROV A, BERESOVA A, KUBIK F, FULA M, OTRUBOVA J, KALATOVA D, KUKUCKOVA E, JURINOVA S, BENCA J, SHAHUM A, HOY LEANG HOINAND CHENG HOIN, SETA $\mathrm{S} /$ Early detection of adverse therapy reaction in orphan children with AIDS (short communication) / In: Acta Missiologica. ISSN 1337-7515. - Vol. 13, no. 2 (2019) p. 184-187.

12. IRWIN / MCGRAW-HILL. ISAKSEN J, SONGSTAD G N, SPISSOY A (2002) Socioeconomic effects of HIV/AIDS in African countries. ChrMichelsen Institute Norway.
Online Available at: www.cmi.no/public/pub 2002.

13. KRCMERY V, BUCKO L, KIMULI D, JACKULIKOVA M, KOZON V, OLAH M, KOVAC R, JANCOVIC M, HOLKOVA J, MIKOLASOVA G, BOZIK J, POLONOVA J, MRAZOVA M, SUVADA J, KOSTICOVA M, HAJDENOVAZ. Cohortation and testing of elderly homeless within COVID pandemics in an urban environment - example of a life island mission model. In: Acta Missiologica. - ISSN 2453-7160 (online) / ISSN 13377515 (print). - Vol. 14, no. 1 (2020) s. 76-78.

14. LEWICKI, R., SAUNDERS, D., MINTON. J. (1997). Essentials of negotiation. Boston, MA.

15. LEWIS J (2009) Work-Family Balance, Gender and Policy. Edward Elgar Publishing, Inc. William Pratt House 9 Dewey Court Northampton Massachusetts 01060 USA. Macionis, J. J. (2012). Sociology. Pearson Publications India.

16. NATIONAL AIDS CONTROL PROGRAM (2017) Online Available at: http://www.nacp. gov.pk/.

17. NAZ A, DARAZ U, MUGHAL I, ALAM A, KHAN W, HUSSAIN M (2012) Pakhtun Social Structure and its Impacts on Women's Education. Global Journal of Human Social Science Linguistics \& Education, Vol. 12 (13).

18. NUEMAN L (2006) Quantitative and Qualitative research methods $\left(6^{\text {th }}\right.$ edi). Pearson Publications India.

19. RIDGEWAY C (2011) Framed by Gender: How Gender Inequality Persists in the Modern World. Oxford University Press, Inc.198 Madison Avenue, New York, New York 10016.

20. RILEY H C, L BABCOCK, MCGINN $\mathrm{K}$ (2003). Gender as a situational phenomenon in negotiation. Carnegie Mellon University.

21. SAUNDERS B, SIM J, KINGSTONE T, BAKER S, WATERFIELD J, BARTIAM B, BURROUGHS H, JINKS C (2017) Saturation in qualitative research: exploring its conceptualization and operationalization. Quality and Quantity: 52 (4).

22. THE UNIVERSITY OF AUCKLAND (no date). About thematic Analysis. Online Avail- 
able at: https://www.psych.auckland.ac.nz/ en/about/our-research/research-groups//thematic-analysis/about-thematic-analysis.html.

23. THE WORLD BANK (2005) HIV/AIDS in Pakistan. Online Available at:www.worldbank.org/saraids.

24. THOMPSON L (1998) The mind and heart of the negotiator. Upper Saddle River, N.J.: Prentice.

25. UNAIDS (2012) Feature Story: HIV increasingly threatens women in Eastern Europe and Central Asia. Online available at:http://www. unaids.org/en/resources/presscentre/featurestories/2012/march/20120312alaskerwomeneeca.

26. WEINI M S, KASHUBA B A (2012) Labor Migration and HIV Risk: A Systematic Review of the Literature. AIDS Behav. Vol; 16(6): 1605-1621.

27. ZOHRY A (2007) Migration and Development in Egypt. Institute for Migration and Cultural Studies (IMIS) Osnabruck University, Germany. 